\title{
Etisalat Gsm Signal Occurrence Indices In The Local Govern ment Headquarters Of Akwa Ibom State, South-South Nigeria.
}

\author{
Augustine A. Umoh, Aniefiok O. Akpan, and Imo Edet Udo \\ ${ }^{1}$ Physics Department, University of Uyo, Nigeria \\ ${ }^{2}$ Physics Department, Akwa Ibom State University, Nigeria.
}

\begin{abstract}
Etisalat GSM occurrence indices in the thirty one (31) local government headquarters of Akwa Ibom State, South- South Nigeria has been examined to know the network signal strength using etrex HC series global positioning system (GPS) navigator receiver equipment, GSM phone ( Nokia 2700C ), signal phone meter and etisalat GSM mast for data collection. It is observed that the number of local government headquarters with $0 \%$ signal strength out-numbered those with $100 \%$ etisalat network signal strength. Those with $100 \%$ signal strength include Abak, Afaha Ikot Ebak, Ikot Ekpene, Mbak Atai, Okoita, Uyo, Etinan, Eket, Ikot Abasi and Oron, others fluctuate to $0 \%$ which is not proper for communication link. Etisalat network users with $0 \%$ signal strength are advised to complain to this telecommunication company so that they can find ways to improve the standard of network strength in their local government headquarters. Network mast should be installed to boost the signal strength in those Local Government Headquarters with low Etisalat network coverage so as to have maximum benefit of service delivery from this telecommunication industry. Professional telecommunication Engineers should be employed to service and maintain the network facilities for optimum performance.
\end{abstract}

Key Words: - Etisalat, Telecommunication, GSM, network, signal strength

\section{INTRODUCTION}

A GSM Network is a network used for cellular telephones (Mouly and Paultet, 1992). The term GSM stands for Global System for Mobile Communications. The network supports digital communication for voice and internet/data services on cell phone networks. Technology updates and regulations for this network are done through the GSM Association. Such network shares many concerns of other communication system such as data services voice communication etc. The Global System for Mobile Communication (GSM) network provides mobile phone services for customers around the world. The network sends compressed digital data out through a structure to provide service and security for customers.

GSM (Global System for Mobile Communications) consists of several kinds of node ( Mayer 1997), the most important nodes relative to this work are the Base Transreceiver Station (BTS) and the Base Station Controller (BSC) that form together the access network of the GSM/GPRS. The Mobile Switching Centre (MSC) is for routing of calls, tracking of the mobile users and security functions. The Visitor Location Register (VLR) is for database storing of actual user related information of users currently served by the mobile switching centre while the Home Location Register (HLR) holds further user information like the actual location and the subscription of data to the users. In radio interface of Global Packet Radio Service (GPRS), there is much core as the GSM core network. Voice traffic is sent to a traditional ISDN-based GSM network while the data traffic is transported via a separated IP-base backbone network.

The two types of node introduced in GPRS are the serving GPRS support node (SGSN) and the gateway GPRS support node (GGSN)(Skoog, 1988). The importance of data communication for today's mobile communication network based for example on the GSM standards being designed mainly for network occurrence is increasing. New requirements for mobile networks are rising as mobile users explore new data services, like sending and receiving e-mails, www-browsing or WAP access with mobile access to IP-based network (e.g. the internet). The increasing need for bandwidth and the special requirements of the busty nature of GSM occurrence network traffic cannot be adequately fulfilled by the General Packet Radio Service ( GPRS) standard.

Global System for Mobile Communication (GSM) is originally from groups of special mobile, it is the most standard for mobile phones in the world including Akwa Ibom State.

GSM which means the Global System for Mobile Communication is used by over 3 billion people across the countries and territories. Its ubiquity makes Akwa Ibom State roaming very common between phones operators thereby enabling subscribers to use their phone in many parts of Akwa Ibom State. GSM differs from its predecessors, in that both signalling and speech channels are digital. The ubiquity of the GSM standard has been an advantage to consumers who benefit from the ability to roam and switch carriers without switching 
phones, and also to network operators who can choose equipment from any of the many vendors implementing GSM.

The GSM network is used around Akwa Ibom State as a network for hundreds of cellular providers. The Etisalat GSM network was designed to handle voice and data communication on a cellular phone. Advanced technology on hand-held data devices use more of the Etisalat GSM features than the standard cellular telephone. The network support voice calls and data transfer-speed up to 9.6kbit (kilobit per second - a measure of the rate of speed for data transfer ( Mouly and Pautet 1992). The network operates at its highest speed in the Akwa Ibom State processing at $1.9 \mathrm{GHz}$.

Etisalat came into existence in 1976 as a joint stock company between International Aeradio Limited, a British Company ( Zept and Rufa1994). The GSM network was developed in 1982 in Europe. The first name of the network was Groupe Special Mobile. It was created by the European conference of postal and telecommunication Administrations. Its original purpose was for use only in Europe, but the first network was launched in 1991 in Finland.

In 1993, the network expanded beyond Europe to 70 carries across 40 countries. In the early 1980s, as business was becoming increasingly international, the telecommunication industry was focused exclusively on local cellular solutions with very few compatible systems. Nevertheless, it was clear there would be an escalating demand for a technology that facilitated flexible and reliable mobile communications.

Emirates Telecommunication, branded trade name as Etisalat which is one of the internet hubs in the state provides connectivity to other telecommunications operators. In October 2011, Etisalat had about 100 exploration agreements covering 14 Local Government Areas Headquarters in Akwa Ibom State out of the 31 Local Governments Headquarters. This enabled blackberry, 3G, GPRS and voice navigation of the network. It was by 2011 that the Federal Government of Nigeria through a law issued out the right to provide the telecommunication wires and wireless services in the state for owning, importing, and manufacturing. It was this that gave Etisalat both regulatory and control powers which broke the monopoly of the telecommunication giant in the Akwa Ibom State. In order to safeguard the states economic development, the law made provisions for the development of the telecommunication sector in the states.

\section{MATERIALS AND METHODS}

Data acquisition was through the use of GSM phone with Etisalat SIM card that has the digital percentage (\%) display as screen saver. Also made use of was GPS (Global Positioning System) that has Latitude $4^{\circ} 33 \square$ and $5^{\circ} 33 \square$ North andlongitude $7^{\circ} 35 \square$ and $8^{\circ} 25 \square$ East. There is an in-built store of data in the GPS where one can stay anywhere in a Local Government Headquarter and observe the network positioning in Etisalat GSM as well as their latitude and longitude. This means that the method of accessing Etisalat Network used for each of the Local Government Headquarter presently is passive and computerised. Serious consideration of the extent to which the sample data collection can be a fair representation of the whole Local Government Areas was taken care of in determining the sample size. Data were collected by direct observation through GSM phone metre that display digital percentage (\%) from $0 \%-100 \%$. The longitude and latitude of each of the Local Government headquarters were observed through the used of Global Positioning System (GPS). The data collected were analyzed through the used of passive methods due to the information and data obtained. The simulation tool was also used to increase the signal traffic and response time of signalling network especially during high traffic load.

\section{RESULTS}

Table 1.0: Etisalat GSM Network Occurrence Data for thirty one (31) Local Government Headquarters of Akwa Ibom State, South-South Nigeria

\begin{tabular}{|c|c|c|c|c|c|c|}
\hline \multirow[t]{2}{*}{$\mathbf{S} / \mathbf{N}$} & \multirow{2}{*}{$\begin{array}{l}\text { Location/ } \\
\text { Village }\end{array}$} & \multirow{2}{*}{$\begin{array}{l}\text { Local } \\
\text { Govt. } \\
\text { Hqts }\end{array}$} & \multicolumn{3}{|c|}{ GSM Signal Occurrence \% } & \multirow{2}{*}{$\begin{array}{l}\text { Remarks/Feat } \\
\text { ures }\end{array}$} \\
\hline & & & Longitude & Latitude & $\%$ & \\
\hline 1. & Abak & Abak & ${\mathrm{E} 007^{\circ} 47.641 \square}$ & N04 $58.757 \square$ & 100 & Mast sighted \\
\hline 2. & Oruk Anam & Ikot Ibritam & $\mathrm{E} 007^{\circ} 40.224 \square$ & ${\mathrm{N} 04^{\circ} 50.811 \square}_{\square}$ & 00 & \\
\hline 3. & Etim Ekpo & Utu Etim Ekpo & E007 $36.508 \square$ & ${\mathrm{N} 04^{\circ} 59.995 \square}_{\square}$ & 00 & \\
\hline 4. & Ika & Urua Inyang & E007 $32.621 \square$ & $\mathrm{N} 05^{\circ} 01.32 \square$ & 00 & \\
\hline 5. & Essien Udim & Afaha Ikot Ebak & $\mathrm{E} 007^{\circ} 40.039 \square$ & ${\mathrm{N} 05^{\circ} 07.781 \square}_{\square}$ & 100 & Mast sighted \\
\hline 6. & Ikot Ekpene & Ikot Ekpene & $\bar{E} 007^{\circ} 43.078 \square$ & ${\mathrm{N} 05^{\circ} 10.685 \square}_{\square}$ & 100 & Mast sighted \\
\hline 7. & Ukanafun & Ikot Akpantuk & $\bar{E} 007^{\circ} 33.983 \square$ & ${\mathrm{N} 04^{\circ} 52.423 \square}_{\square}$ & 00 & \\
\hline 8. & Obot Akara & Nto Edino & E007 $30.972 \square$ & N04 $50.413 \square$ & 00 & \\
\hline 9. & Ikono & Ibiaku Ntok Okpo & $\mathrm{E}^{2} 07^{\circ} 42.899 \square$ & N05 $16.875 \square$ & 00 & \\
\hline 10. & Ini & Odoro Ikpe & $\bar{E} 007^{\circ} 44.828 \square$ & ${\mathrm{N} 05^{\circ} 21.397 \square}_{\square}$ & 60 & \\
\hline
\end{tabular}


Etisalat Gsm Signal Occurrence Indices In The Local Government Headquarters Of Akwa Ibom State,

\begin{tabular}{|c|c|c|c|c|c|c|}
\hline 11. & Itu & Mbak Atai & $\mathrm{E}^{2} 07^{\circ} 59.902 \square$ & ${\mathrm{N} 05^{\circ} 10.307 \square}$ & 100 & Council Hqts \\
\hline 12. & Ibiono Ibom & Oko Ita & $\mathrm{E}^{2} 07^{\circ} 53.629 \square$ & ${\mathrm{N} 05^{\circ} 11.401 \square}$ & 100 & \\
\hline 13. & Uruan & Idu & E007 $00.887 \square$ & ${\mathrm{N} 05^{\circ} 01.696 \square}$ & 70 & \\
\hline 14. & Uyo & Uyo & E007 $55.406 \square$ & $\mathrm{N}^{\circ} 5^{\circ} 2.152 \square$ & 100 & Mast sighted \\
\hline 15. & Ibesikpo Asutan & Nung Udoe & E007 $57.695 \square$ & ${\mathrm{N} 05^{\circ} 54.898 \square}_{\square}$ & 00 & \\
\hline 16. & Nsit Atai & Odot & $\overline{\mathrm{E} 007^{\circ} 02.279 \square}$ & 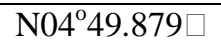 & 00 & \\
\hline 17. & Nsit Ibom & Afaha Offiong & ${\mathrm{E} 007^{\circ} 54.050}$ & ${\mathrm{~N} 04^{\circ} 52.431 \square}$ & 00 & \\
\hline 18. & Nsit Ubium & Ikot Edibon & E007 55.810 & $\mathrm{~N} 04^{\circ} 46.210 \square$ & 00 & \\
\hline 19. & Etinan & Etinan & $\mathrm{E} 007^{\circ} 51.320 \square$ & $\mathrm{N}^{\circ} 4^{\circ} 50.053 \square$ & 100 & Mast sighted \\
\hline 20. & Eket & Eket & $\mathrm{E} 007^{\circ} 55.715 \square$ & ${\mathrm{N} 04^{\circ} 38.533 \square}$ & 100 & \\
\hline 21. & Onna & Abat & E007 $53.738 \square$ & $\mathrm{N} 05^{\circ} 37.521 \square$ & 95 & \\
\hline 22. & Mkpat Enin & Mkpat Enin & $\mathrm{E}^{2} 07^{\circ} 44.976 \square$ & ${\mathrm{N} 05^{\circ} 44.020 \square}$ & 00 & \\
\hline 23. & Ikot Abasi & Ikot Abasi & ${\mathrm{E} 007^{\circ} 33.152 \square}$ & $\mathrm{N}^{\circ} 5^{\circ} 34.098 \square$ & 100 & \\
\hline 24. & Eastern Obolo & Okoroete & E007 $44.904 \square$ & $\mathrm{N}^{\circ} 4^{\circ} 33.141 \square$ & 30 & \\
\hline 25. & Esit Eket & Uquo & $\mathrm{E} 008^{\circ} 03.582 \square$ & $\mathrm{N}^{\circ} 4^{\circ} 03.582 \square$ & 100 & \\
\hline 26. & Ibeno & Ukpene-kang & E007 58.563 & ${\mathrm{~N} 04^{\circ} 34.203 \square}$ & 10 & \\
\hline 27. & Mbo & Enwang & E008 ${ }^{\circ} 15.017$ & $\mathrm{~N} 04^{\circ} 39.055 \square$ & 00 & \\
\hline 28. & Udung Uko & Eyofin & E008 14.230 & ${\mathrm{~N} 04^{\circ} 46.344 \square}$ & 100 & \\
\hline 29. & $\begin{array}{l}\text { Urue-Offong/ } \\
\text { Oruko }\end{array}$ & Urue Offong & $\mathrm{E} 008^{\circ} 09.866 \square$ & $\mathrm{N} 04^{\circ} 45.110 \square$ & 40 & \\
\hline 30. & Oron & Oron & $\mathrm{E} 008^{\circ} 13.460 \square$ & $\mathrm{N} 04^{\circ} 48.500 \square$ & 100 & $\begin{array}{l}\text { Maritime } \\
\text { Junction }\end{array}$ \\
\hline 31. & Okobo & Okopedi & $\mathrm{E} 007^{\circ} 07.560 \square$ & $\mathrm{N} 04^{\circ} 50.900 \square$ & 00 & \\
\hline
\end{tabular}

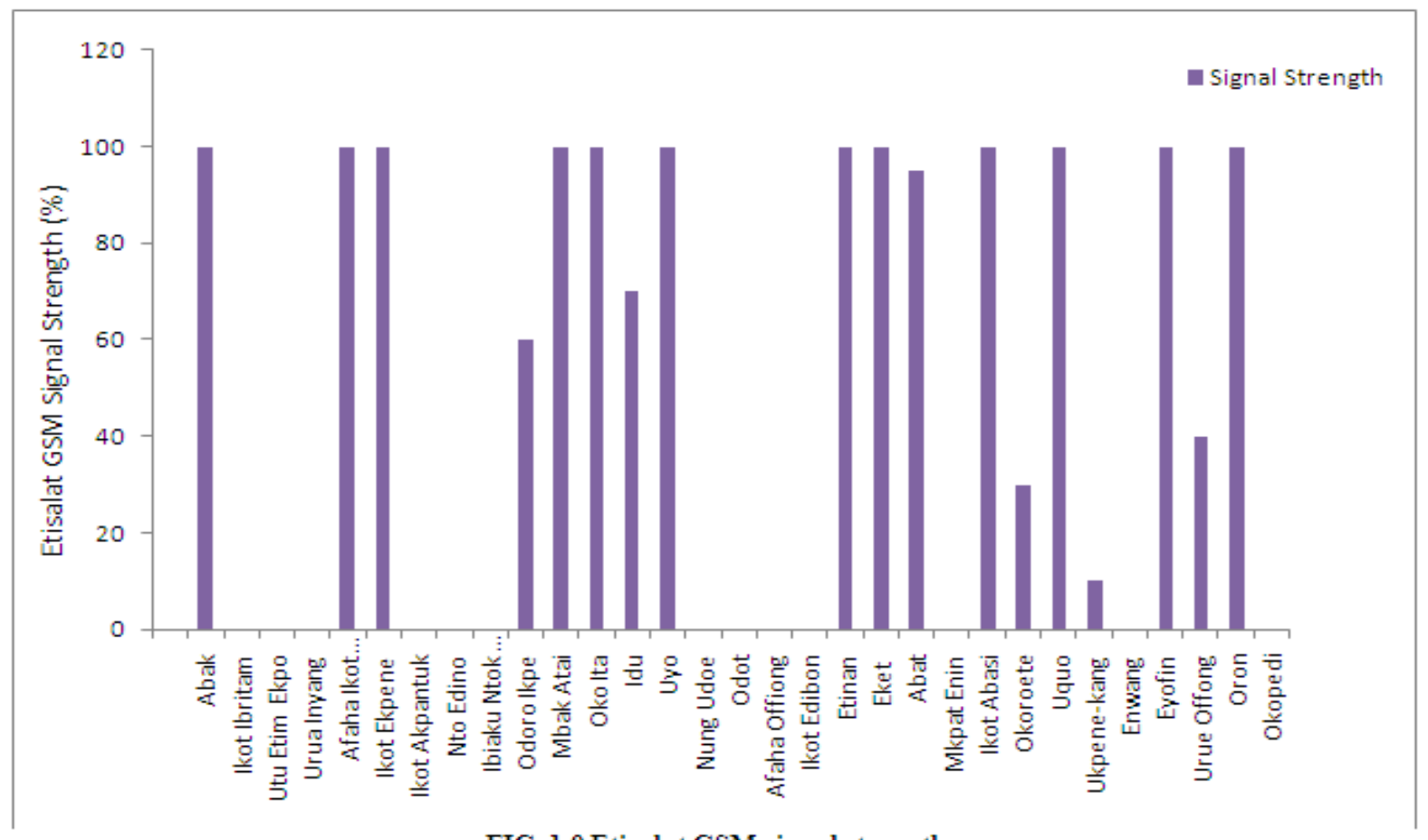

FIG. 1.0 Etisalat GSM signal strength

\section{DISCUSSION OF RESULTS}

Figure 1.0 shows how the Etisalat GSM signal strength occur for each of the Local Government Area Headquarters of Akwa Ibom State. It can be observed that the network signal strength in Abak, Afaha Ikot Ebak and Ikot Ekpene was up to 100\% which give better occurrence of Etisalat network to the people around these Local Government Headquarters . But the Etisalat network was 0\% in Ikot Ibritam, Utu Etim Ekpo, Urua Inyang, Ikot Akpantuk, Nto Edino and Ibiaku Ntok Okpo. The Etisalat GSM network occurrence in Mbak Atai, Okoita, Uyo, Etinan and Eket is 100\%. The Etisalat GSM network in Idu fluctuated to $70 \%$ but in Nung Udoe, Odot, Afaha Offiong and Ikot Edibon their network dropped to 0\% which means people leaving around those Local Government Headquaters cannot communicate with Etisalat Network. Abat, Ikot Abasi, Uquo, Eyofin and 
Oron has $100 \%$ network occurrence but in Okoroette, the network fluctuated to $30 \%$. The network signal was $40 \%$ to $100 \%$ in Urue Offong and Ukpenekang and their longitude and latitude also differ.

Table 1.0 shows that latitude and longitude of each Local Government Headquarters differ base on their direction . Abak Local Government Headquarter has a latitude of N04 ${ }^{\circ} 58.757 \square$ and longitude E007 $47.641 \square$, Ikot Ibritam has a latitude of $\mathrm{N} 04^{\circ} 50.811 \square$ and longitude E007 $40.224 \square$ while Utu Etim Ekpo has a latitude N04 ${ }^{\circ} 59.995 \square$ and longitude of E00736.508 $\square$. From the analysis we can observe that all the values of the longitude are measured in East direction while the latitude are measured in North direction.

The latitude and longitude of a particular Local Government Headquarter depends on the value of it direction from Global Positioning System (GPS). The longitude for Abat is E007 $53.738 \square$ and is latitude is N04 $37.521 \square$, also in Mkpat Enin the longitude is E007 $44.976 \square$ whilelatitude is N04 $44.020 \square$. For Oron and Uquo we can see that their signal strength occurrence is the same (100\%) but their longitude and latitude differ. This means that, signal strength occurrence of one Local Government Headquarters can be the same as the other but differ in their longitude as well as latitude.

\section{CONCLUSION}

From the results of the Etisalat GSM network signal strength occurrence for the 31 Local Government Headquarters of Akwa Ibom, it has shown that this network has great impact on the users in this state. The result shows that the percentage signal strength for Abak, Afaha Ikot Ebak, Ikot Ekpene, Mbak Atai, Okoita, Uyo, Etinan, Eket, Abak, Ikot Abasi, Eyo Abasi and Oron has a full Etisalat network occurrence with $100 \%$. But others fluctuate from $0 \%$ which is not proper for communication link. The analysis also shows that the number of Local Government Headquarters with 0\% signal strength is more than the number of Local Government Headquarters with $100 \%$ Etisalat network signal strength. The Etisalat network users with less than $100 \%$ signal strength should lay complains to Etisalat Telecommunication Company for the improvement of the standard of network strength in their Local Government Headquarters for quality service delivery. Network mast should be installed to boost the signal strength in those Local Government Headquarters with low Etisalat network coverage, so that they can achieve maximum benefit from this telecommunication industry.

\section{RECOMMENDATIONS}

To achieve its corporate goals and objectives, the Etisalat Telecommunication Company needs to improve on their network signal occurrence in all the 31 Local Government Headquarters of Akwa Ibom State. To achieve this, there should be installations of Etisalat GSM mast in all the 31 Local Government Headquarters of Akwa Ibom State through which there will be ease of communication link. Professional telecommunication Engineers should be employed to service and maintain the facilities. The company should develop and acquire appropriate trust to all staff especially network engineers to make sure that Etisalat network signal is present every time. We however strongly commend the effort of Etisalat telecommunication company for the services rendered so far to the people of Akwa Ibom State, Nigeria.

\section{REFERENCES}

[1] Adeleke, O. B. (1968): Certificate physicals and human geography. Pp. 9 - 11.

[2] Ernest, C. A. (2003). Telecommunication in National Development .Internet. http://www. DCC.gov.ng/article.

[3] Jacqueline, G. And Bruce, P. (1997): Link delays in signalling system. No. 7 Networks. Pp1199 - 1208.

[4] Lili, G. (2001): Telecommunication technology fundamental. Internet.http://www.aroprofessional.com.

[5] Mouly, M. And M. B. Pautet (1992): The GSM system for Mobile Communication.

[6] New Encyclopedia Britannica (1998). Encyclopedia Britannica Inc. U.S.A. vol. 11 pg. 617.

[7] Pain, J. H. (2005). The Physics of vibration and waves. $6^{\text {th }}$ Edition, pg. 112.

[8] Paul, A. T. (1991): Physics for Scientist and Engineers. $3^{\text {rd }}$ Edition, Worth Publishers, New York, Vol. 2 pg. $957-959$.

[9] Raymond, A. and John, W. (2003): Physics for Scientists and Engineers with modern physics. Pp. 503 505 .

[10] Skoog, R. A. (1988): Engineering common channel signalling network for ISDN. In proceeding of the $12^{\text {th }}$ International Teletraffic Congress (ITC). Pp 2.4A1.1 - 2.4A1.7.

[11] World Book Encyclopedia (1992): World Book Inc. USA Vol. 19, pp 100 - 112.

[12] William, J. M. (1997). Congestion control interactions with multiple user part in processing teletraffic congress (ITC) pp. $1189-1198$.

[13] Zept, J. and G. Rufa (1994). Congestion and flow control in signalling system. No. 7 - (Impacat of intelligent networks and new services). IEEE journal on selected areas in telecommunication vol. 12, pp. $501-509$. 